\title{
Obituary
}

\section{José Cavalcante de Souza, 1925-2020}

"You have to feel the atmosphere of the dialogues", said Professor Cavalcante while, as a storyteller, he presented Plato's main works to us-I was a freshman at the Philosophy Department of the State University of Campinas, in 1993. Unfailingly, he would burst into tears in the end of the class, so strong was his affection for Plato's art, "the greatest writer of the West", as he always said. Although we eventually got used to his sentimental temperament, we did feel bewildered when we first saw that densely grey-haired old man clean his damp glasses, impersonate Socrates, paraphrase the Protagoras' denouement and, his voice choking, say: "here we are, overcome by the logos". That was incomprehensible to us then, but already awe-inspiring. His classes on Homer were not different from those on Plato.

I believe these were the last classes that Professor Cavalcante gave at the State University of Campinas. Retired from the University of São Paulo in 1988, where he held the chair of Classics for decades, he moved to Campinas in order to play a decisive role in the establishment of the Department of Philosophy, being its active member until Brazilian law forced him to retire for good in 1994. His presence at the University of Campinas was determinant also for the consolidation of classical studies there, which were but incipient at the time.

Born in Cariús, in the State of Ceará (Northeast of Brazil), he began his classical studies at the Catholic Faculty of Philosophy, in Fortaleza, teaching French at the Alliance Française at the same time. In 1951, with a study grant from this institution, Professor Cavalcante spent a couple of years in France, where he had the opportunity to delve into the classics. Back in Brazil, he moved to São Paulo in 1953, teaching Latin in colleges until 1956, when he became Professor at the Department of Classics, Sciences and Letters of the University of São Paulo. He was the first person to receive a Doctor's Degree in Classics from a Brazilian university - his dissertation was a translation of Plato's Symposium, 
under the supervision of French Professor Robert Henri Aubreton, then working at the University of São Paulo. This translation, published in 1966 (Difel), remains a paradigm of elegance and philosophical rigor that all Brazilian translators of this dialogue-me included - strive to emulate.

During his years in São Paulo, he also published A Caracterização dos Sofistas nos Primeiros Diálogos de Platão ["The Characterization of the Sophists in Plato's Earlier Dialogues"] (USP, 1969), a sort of thèse d'agrégation, and edited the volume dedicated to the Pre-Socratic philosophers in the popular Brazilian collection of philosophy "Os Pensadores" ["Thinkers"] (Abril Cultural, 1973). This volume contained Professor Cavalcante's original and influential translations of the first philosophers, especially Heraclitus and Parmenides. After several seminal publications, in 2016, he published his last work, the translation of Plato's Phaedrus (Editora 34), as beautiful and poignant as his translation of the Symposium.

Measured by the scholarly standards of our publish-or-perish era, Professor Cavalcante's published works seem unimpressive for so many years in activity. Such a judgement, however, would be entirely inappropriate. First of all, one has to have in mind the excellence and pioneering nature of his work: he has bequeathed us nothing that is not brilliant. Second, his perfectionism did not allow him to publish for the sake of publishing: no one really knows which and how many articles and translations Professor Cavalvante left unpublished. Still unpublished, as far as I know, are his numerous translations of Greek lyric poets, all of Pindar's Odes among them, the entire Iliad and Odyssey, Aristotle's Metaphysics, and other dialogues of Plato as well. His translations, usually the first ones made directly from the Greek among us (it was not uncommon that Greek authors were indirectly translated from English and French translations), circulated in typewritten copies and, very often, were the only reliable material we had to read in Portuguese. Third, and perhaps more importantly, Professor Cavalcante was, literally, the father of us all, Brazilian classicists, for he has taught, directly or indirectly, all generations of Brazilian scholars until now. To name a few: Jacyntho Lins Brandão (UFMG); JAA Torrano, Filomena Hirata and Paula da Cunha Corrêa (USP); Francisco Achcar, Trajano Vieira, Flávio Ribeiro de Oliveira, Lucas Angioni, Hector Benoit (Unicamp). Even the eminent Brazilian poet Haroldo de Campos was his student of Greek for a few years.

Much could, and should, be said about Professor Cavalcante's activity during the years Brazil was under a military dictatorship, when many professors were persecuted, and about his engagement in the administrative functions that have made Brazilian classical studies possible. But it would be hard and 
lengthy to explain it to readers unfamiliar with Brazilian history and the structure of our university system.

Generous, always smiling, cheerful, affable, and passionate about his profession; deeply and truly erudite; fount of a knowledge of ancient Greek language and literature rivalled by few. There is no factor to measure Professor Cavalcante's impact on Brazilian classical studies. We became orphans on the 23rd May, 2020.

José C. BaracatJr.

Universidade Federal do Rio Grande do Sul, Porto Alegre—RS, Brazil baracatjr@hotmail.com 